\title{
COVID-19 and Immigrants' Increased Exclusion: The Politics of Immigrant Integration in Chile and Peru
}

\author{
Luisa Feline Freier ${ }^{1 *}$ and Marcia Vera Espinoza ${ }^{2 *}$ \\ ${ }^{1}$ Departamento de Ciencias Sociales y Politicas, University of the Pacific, Lima, Peru, ${ }^{2}$ School of Geography, Queen Mary \\ University of London, London, United Kingdom
}

\section{OPEN ACCESS}

Edited by:

Jaya Ramji-Nogales,

Temple University, Philade/phia, PA,

United States

Reviewed by: Melissa Martins Casagrande, Universidade Positivo, Brazil Cristián Doña-Reveco, University of Nebraska Omaha, United States Victoria Finn,

Diego Portales University, Chile; Leiden University Leiden, Netherlands, in collaboration with reviewer $C D-R$

*Correspondence: Luisa Feline Freier If.freierd@up.edu.pe Marcia Vera Espinoza m.vera-espinoza@qmul.ac.uk

Specialty section: This article was submitted to Migration and Society,

a section of the journal Frontiers in Human Dynamics

Received: 05 December 2020 Accepted: 28 January 2021

Published: 10 March 2021

Citation:

Freier LF and Vera Espinoza M (2021) COVID-19 and Immigrants' Increased Exclusion: The Politics of Immigrant Integration in Chile and Peru.

Front. Hum. Dyn 3:606871. doi: 10.3389/fhumd.2021.606871
The COVID-19 pandemic has put into sharp relief the need for socio-economic integration of migrants, regardless of their migratory condition. In South America, more than five million Venezuelan citizens have been forced to migrate across the region in the past five years. Alongside other intra-regional migrants and refugees, many find themselves in precarious legal and socio-economic conditions, as the surge in numbers has led to xenophobic backlashes in some of the main receiving countries, including Chile and Peru. In this paper, we explore in how far the COVID-19 crisis has offered stakeholders an opportunity to politically reframe migration and facilitate immigrant integration or, rather, further propelled xenophobic sentiments and the socio-economic and legal exclusion of immigrants.

Keywords: COVID-19, South America, venezuelan displacement, immigrant integration, immigrant exclusion, xenophobia

\section{INTRODUCTION}

While the COVID-19 pandemic has shed light on the need for social integration of migrants and refugees, it has also revealed the lack of sustainable inclusion and integration policies across different countries of destination. In South America, the above-mentioned is evidenced by the exacerbated vulnerabilities of migrant and refugee populations, as a result of the COVID-19 crisis, and their general lack of inclusion in social policies and emergency responses to the pandemic across the region (Bengochea et al., 2020; Vera Espinoza et al., Forthcoming). In this paper we explore the policy and political responses in Chile and Peru, interrogating whether migrants and refugees were included in COVID-19 responses, but also whether the sanitary crisis has facilitated immigrant integration or further propelled their exclusion more broadly.

Neighboring Chile and Peru are relevant cases as these two South American countries have seen a sharp increase in intraregional migration in recent years and are among the main destinations for Venezuelan migrants and refugees $(\mathrm{R} 4 \mathrm{~V}, 2020)^{1}$. While Chile turned into a destination of intraregional migration in the 2000s (Doña-Reveco and Levinson, 2012), and hosts migrants from a variety of different origins, Peru has only recently transitioned from an emigration to a transit and destination country of predominantly Venezuelan immigrants (Berganza and Freier, 2021). Similarities and differences between the two countries allow for a comparative analysis that is

\footnotetext{
${ }^{1}$ It has been argued that Venezuelans ought to be recognized as refugees according to the incorporation of the Cartagena definition of refugee in domestic refugee laws across the region (Berganza et al. 2020; Freier et al. 2020). However, recognition rates remain low. We thus refer to Venezuelan "migrants" in this paper, while recognizing the largely forced character of their displacement and the obligation of Latin American states, including Chile and Peru, to recognize them as refugees.
} 
pivotal for the understanding of immigrant inclusion in these specific cases, and at the same time also invite us to reflect about the region more broadly.

The COVID-19 crisis hit South America in the middle of the massive displacement of more than five million Venezuelans citizens, $80 \%$ of who have settled in the region (R4V, 2020). Although less visible, there are other migrant groups whose vulnerability has also increased during the pandemic (Vera Espinoza et al., 2020). In this context, the actors involved in immigration governance continue to make sense of immigration-trying to understand what is happening and what to do next-not only in relation to the increased numbers of immigrants, public opinion, and political considerations (Geddes et al., 2019), but also in view of how to deal with migrants and refugees in the context of the COVID19 sanitary crisis. Thus, immigration policy responses to the pandemic need to be understood in the context of policies and political discourses both prior and during the pandemic.

We argue that both Chile and Peru's emergency responses to the pandemic have jeopardized any timid efforts of immigrant integration, as migrants are framed as another "crisis" within the crisis or even as responsible for the sanitary crisis (Vera Espinoza et al., Forthcoming; Mazza, 2020). While migrants have been key actors in mitigating the impacts of the health and economic crisis during the pandemic (as essential workers in health-related areas, as well as in the entire food supply chain), COVID-19 has exacerbated their precarious conditions (Bengochea et al., 2020; Luzes et al., 2020; Zapata and Prieto Rosas, 2020). It is important to note that the integration barriers that migrants face are not determined by COVID-19 alone, but by the significant gaps in social and labor conditions between native and migrant populations, as well as by the lack of effective policy responses.

In this paper, we contribute our understanding of law and policy responses to COVID-19 in two South American countries, while reflecting on immigration policies and politics of integration in the region more broadly. More specifically, we explore political narratives and policy reactions both before and during the pandemic, and how they were embedded in media discourses and changing public opinion. We address the question whether COVID-19 has led the Chilean and Peruvian governments to take any concrete measures targeting migrants and refugees, as part of their emergency response, and in how far the sanitary crisis has led to discursive changes in political discussions that are likely to influence immigration policies beyond the pandemic.

For the purpose of this study, we adopt a narrow understanding of integration, which focuses on the incorporation of migrants and refugees in the formal labor market and their access to social services, such as education, healthcare, and social protection programs. Traditionally, "integration" has been understood as the incorporation of legal immigrants or naturalized citizens in their host societies, whereas the term "inclusion" is broader and conveys that the migrant experiences a sense of security, stability and predictability with a view to the future, irrespective of her legal status (Cook, 2013). Indeed, undocumented immigrants can also be bureaucratically incorporated through schools and social services (Marrow, 2009) and socially and economically included as workers, consumers and neighbors (Cook, 2013). In this paper we refer to integration and inclusion, as they both convey intertwined structural and social processes that are at play in the context discussed here. While interdisciplinary bodies of literature have largely recognized that integration is a multidimensional process across diverse structural and social dimensions (Gidley, 2014), less attention has been paid to the role of political discourses in shaping these processes of inclusion and associated policies in the context of the pandemic.

Our analysis is based on a review of selected government declarations, decrees, and media reports in relation to the COVID-19 sanitary crisis up until September 2020, and informed by the preliminary analysis of 20 interviews with key actors (central and local governments, NGOs, migrant organizations and international organizations) that we conducted in Chile and Peru between June and August $2020^{2}$. In the case of Chile, we focus on two of the largest migrant groups: Venezuelans and Haitians, that respectively represent $30.5 \%$ and $12.5 \%$ of the total foreign population (INE-DEM, 2020). In the case of Peru, we focus on policies targeting, and narratives surrounding, Venezuelan immigration, given that they made up $84.4 \%$ of all foreigners in Peru by the end of 2019 (Andina, 2019). For each country, we briefly present the context of the rising number of migrants, and how these had affected processes of sense-making among policy makers and consequent immigration policies pre-COVID-19. We then turn to analyze the changes in narratives and broader immigration policies during the pandemic, in order to reflect upon their impact on migrant and refugee integration.

\section{CHILE}

\section{Rising Immigration and Political Salience}

The increase of intraregional migration in South America has been particularly significant in Chile (Stefoni and y. Brito, 2019). The country's migrant population increased from $1.3 \%$ in 2002, to $4.4 \%$ in 2017 (CEPAL, 2019), to almost constituting $8 \%$ of the total population by the end of 2019 , when the foreign-born population residing in Chile was almost 1.5 million people (INE-DEM, 2020). The main migrant groups in Chile come from Venezuela (30.5\% of the total immigrant population), Peru (15.8\%), Haiti (12.5\%), Colombia (10.8\%), and Bolivia (8.0\%) (INE-DEM, 2020). The 2017 Census shows that most migrants live in the Metropolitan Region of Santiago (65.3\%), as well as in the northern regions of Antofagasta (8.4\%), Tarapacá (5.9\%), and the region of Valparaíso (5.4\%) (INE, 2018).

Overall, the majority of immigrants in Chile come from other Latin American countries and the Caribbean, mainly as a result of humanitarian or political and economic crisis (Jubilut et al.,

\footnotetext{
${ }^{2}$ The research for this paper has been conducted in the context of a larger study by the research group CAMINAR (Comparative Analysis in International Migration and Displacement in the Americas) (Bengochea et al. 2020; Vera Espinoza et al., 2020; Zapata and Prieto Rosas 2020).
} 
2021); facilitated by sub-regional mobility regimes (MERCOSUR) (Brumat, 2020); or as a result of the increasing border and migration restrictions imposed by the global north (Stefoni and y. Brito, 2019). Alongside the growing numbers of immigrants, there has been a well-documented politicization of migration in Chile (Acosta et al., 2018; Thayer, 2019), with increased presence in the political agenda and the media.

Public perception surrounding immigration has also grown more polarized and complex in the last few years. In 2018, a survey by Ipsos recorded that $53 \%$ of Chileans agreed that migration was "beneficial" to the country, while $43 \%$ viewed it as "harmful" (Ipsos 2018). Another survey conducted by the Universidad Andrés Bello and the Ministry of Interior in June 2020 - amid the COVID-19 pandemic-, showed that 57\% of Chileans thought that the amount of migrants living in the country should decrease, and that $70 \%$ agreed that visas should not be given to migrants who entered the country through irregular channels (UNAB-DEM, 2020). An analysis of the Centro de Estudios Públicos (CEP) national surveys of 2003 and 2017 further shows that throughout this period one in three Chileans thought that immigrants contributed to the economy (González et al., 2019). At the same time, however, the perception that immigrants increased crime grew by $6 \%$ since 2003 , reaching $41 \%$ in 2017 . Overall, and despite the increased presence in media and political discourses, "immigration" remained of low concern to Chileans in comparison with other issues. When asked to identify three key issues the government should solve in the CEP public opinion survey in December 2019, only $1 \%$ chose migration, compared to pensions (64\%), health (46\%) and education (38\%). The latter concerns were reflected in the demands raised during the national social protests that took place in Chile in late 2019.

\section{Pre-COVID Narratives and Policies}

In April 2018, and only one month after starting his second administration, Chilean President Sebastián Piñera announced a "migration reform" that included some modifications to the migration bill sent to Congress during his first government in 2013, as well as a series of executive measures that aimed to "clean up the house" (Acosta et al., 2018). This statement referred to dealing with the perceived "chaos," brought on by the increased numbers of migrants, by combating irregular immigration through the creation of six new visas, as well as announcing a process of regularization $^{3}$ (Finn and Umpierrez de Reguero, 2020; Thayer, 2019). Chile's current immigration law dates back to 1975 (Decree-Law No. 1094) and was decreed under the military dictatorship of Augusto Pinochet. Piñera's migration bill (Boletín No 8.970-06) was approved by the Deputies of Chamber in January 2019 (Interior 2019), and then by the Senate at the beginning of December 2020 (Gobierno de Chile, 2020).

Piñera's "migration reform" installed migration as one of the priorities of his administration and positioned the topic in the

\footnotetext{
${ }^{3}$ According to the government, this process was going to allow the regularisation of more than 300,000 immigrants in a period of 3 months. By the end of the process, 155,000 immigrants participated in the process (Navarrete and Vedoya, 2019).
}

media. Alongside the modifications to the bill, Piñera issued two executive decrees to change visa procedures for Venezuelan and Haitian migrants (Acosta et al., 2018). These executive decrees created the Visa of Democratic Responsibility for Venezuelans, which can be issued in any Chilean consulate abroad but is subject to specific requirements such as a passport (or ID national card) and proof of non-criminal record, and a consular tourist visa for Haitians. As in other countries, such as Ecuador and Peru, these visas represent de facto barriers to legal entry for the targeted nationalities (Freier and Luzes, 2021). At the same time, the government reinforced the practice of mass deportations, as a key feature of a communication campaign that criminalizes migration, reproducing ideas about "good" and "bad" migrants (Stefoni and y. Brito, 2019; Brumat and Vera Espinoza, Forthcoming).

The increased salience of immigration in governmental discourses continued alongside two major events in Chile: the social protests of 2019 and the subsequent constitutional process that started with the plebiscite in 2020. While the public, as shown above, was more concerned about the social demands, an exclusionary rhetoric about immigrants persisted. Such as the wrongful accusation that linked the social protests to "Cuban and Venezuelan migrants" that aimed to destabilize the country (La Tercera, 2019). Despite these challenges, migrant-led groups have sought to take an active participation in these social processes (Red de Migrantes por el Apruebo, 2020).

\section{Narratives and Policies in the Context of COVID-19}

Chile reported its first confirmed COVID-19 case on March 3, 2020 (IMF, 2020). On March 18, 2020, the Chilean government declared a state of emergency (Decree No 104), and closed its borders for a period of 90 days, except in the case of Chileans and foreign residents in Chile (Decree No 102, March 16, 2020). As in many other South American countries, the army was sent to reinforce the borders (Bengochea et al., 2020). In addition, a nationwide curfew $(10 \mathrm{pm}-11 \mathrm{pm}$ to $5 \mathrm{am})$ has been in place since March 22 (Exempt Resolution No 202). Alongside these measures, the government's emergency plan included territorial quarantines in specific municipalities and cities, declared through exempt resolutions, as well as sanitary cordons ${ }^{4}$. These measures have translated into increased police control, closure of commerce, and changes to the transport system, all of which have impacted migrants' livelihoods and mobility (Bengochea et al. 2020).

The government also announced a series of social protection measures in order to deal with the economic impacts of the pandemic. At the end of March, the government enacted the "Bono COVID-19" (Law No 21225), by which the government provided a bonus of $\$ 50,000$ Chilean pesos (USD\$60) that sought to reach $60 \%$ of the most vulnerable members of Chilean society. On May 14, the government enacted Law No 21230 "Emergency

${ }^{4}$ The entire action plan of the government and updated measures can be reviewed at the https://www.gob.cl/coronavirus/plandeaccion/ 
Family Income," aimed at helping families working in the informal sector, whose income was most severely affected by the sanitary crisis. To receive this benefit, one must be included in the Social Registry of Homes (Registro Social de Hogares) and have a valid Chilean ID (Cédula de Identidad). This means that irregular migrants, or those with expired IDs, cannot access these benefits, including immigrants who have initiated their regularization process, but who have not yet received their IDs (Ambiado et al., 2020; Vera Espinoza et al., Forthcoming).

In the context of COVID-19, the Chilean government has also seen the increasing digitalization of visa and documentation procedures. This digitalization process did not emerge exclusively due to the pandemic, but it was certainly accelerated by it. Already in January 2020, the Department of Immigration and Foreign Nationals (DEM by its acronym in Spanish) had announced that certain procedures, such as applications for permanent residence, travel certificates, and payment of fines could be done online, in order to improve waiting times (Sub Interior 2020). However, some of our interviewees ${ }^{5}$, as well as comments from migrants on DEM's social networks, have reported increased waiting times and delays in responses, as well as failures in the online platform. The government also granted an extension to the validity of identity cards for a period of 1 year (Ministerio de Justicia y Derechos Humanos (MJDDHH), 2020), and extended the period to switch employers for immigrants on work visas ${ }^{6}$ from 30 to 180 days (Carreño, 2020).

According to the government, as emphasized in our interviews ${ }^{7}$, all the measures taken in relation to the pandemic are "transversal" to the entire population. However, this "whole society" rhetoric, in relation to the government's pandemic response, does not necessarily translate into the implementation of benefits for migrant and refugee populations $^{8}$, particularly those with expired documentation and in an irregular situation (Ambiado et al., 2020). For example, the digitalization has not included asylum applications, and most of them are on standby as governmental offices are closed, leaving asylum seekers in limbo. Two Court decisions (one in Iquique ${ }^{9}$ and one in Puerto Montt $^{10}$ ) have pushed the government to accept the

${ }^{5}$ Interview with migrant-led organization's representative, June 18, 2020; interview with staff of NGO in Arica, July 7, 2020.

${ }^{6}$ This process can only be done online if the person resides in the Metropolitan Region, for all the other regions migrants need to book an appointment and go to the relevant office in person https:/www.extranjeria.gob.cl/trabajar-en-chile/visasujeta-a-contrato/cambio-de-empleador-de-visa-sujeta-a-contrato

${ }^{7}$ Interview with official from the Chilean government, July 6, 2020.

${ }^{8}$ As documented by Finn and Umpierrez de Reguero (2020), the Chilean government has already used "inclusive language for exclusive policies" in relation to some of the measures taken as part of the migration reform announced in 2018.

${ }^{9}$ Information available at https://www.indh.cl/ante-solicitud-indh-y-por-covid-19corte-de-iquique-ordena-tramitacion-de-solicitud-de-refugio-via-correo-

electronico/

${ }^{10} \mathrm{https} / /$ www.soychile.cl/Puerto-Montt/Sociedad/2020/07/23/665529/Ordenana-la-Gobernacion-de-Llanquihue-acoger-a-tramite-solicitud-de-refugio-de-cincociudadanos-extranjeros.aspx asylum applications of two families by email, without yet resulting in concrete policy changes to the asylum procedures.

Despite the "transversality" claimed by the government, there has not been a coordinated action. While the Ministry of Foreign Affairs has been actively dealing with the return of some migrant groups, the DEM at the Ministry of Interior has been handling visa procedures and the extensions granted to specific documentation or processes. Other ministries are leading general social, labor, and epidemiological responses, some of which do not target immigrant populations.

Besides the emergency measures taken by the government, the municipalities have played a key role in addressing the concerns of migrants. They have also helped cover the essential material needs of migrants who wanted to return to their countries of origin, or to another country in the region, but who were unable to do so as result of border closures and sanitary measures within these countries, as it was-and still is-the case of Peruvian, Bolivian, Colombian, and Venezuelan migrants (Vera Espinoza et al., 2020). International organizations, local NGOs, and migrant-led organizations have also had a crucial role, mainly in providing food parcels, shelter, some cash transfers, and translating key information to different languages (Vera Espinoza et al., Forthcoming).

As reported by the local media, and supported by our interviewees ${ }^{11}$, exclusion also emerges from unclear information, as well as from a growing climate of racism and xenophobia, which is present in both the government and part of the media. Indeed, the government and some media outlets associated the rising numbers of COVID-19 cases to irregular migration since April (Vera Espinoza et al., 2020). Although official records indicate that the virus entered Chile via a Chilean traveler returning from Singapore in early March (BBC Mundo, 2020), Piñera said in a televised statement on April 10, 2020, that the borders needed to be strengthened to "prevent "illegal" immigration from bringing the infection with the virus into our country" (Prensa Presidencia, 2020). Similar comments were made by the Minister of Health. Around the same time, some media outlets started to use images that associated COVID19 and the migrant population, especially black migrants, such as the cover page of the newspaper La Segunda on April 7th, which featured a Haitian woman holding a baby in her arms with the headline "Infections stabilize." Migrant organizations, NGOs, and academics have issued rejection letters and statements against these expressions, which are "indicative of discrimination against the international migrant population" (El Mostrador 2020).

It is relevant to note that xenophobia against migrants in Chile was already well documented before the pandemic (Tijoux and Ambiado, 2019; Bonhomme, 2021) and that misleading accusations against migrants as vectors of disease, such as HIV and Tuberculosis, are not new in the country (see discussion in Cabieses et al., 2019). During the pandemic, there has been

\footnotetext{
${ }^{11}$ Interviews with migrant-led organization's representative, June 18, 2020; interview with staff of NGO in Santiago, July 13, 2020; and interview NGO member in Arica, July 20, 2020.
} 
recorded cases of racism, such as the one experienced by a group of Haitians living in an overcrowded accommodation in Quilicura, Santiago, who tested positive for coronavirus. The local authorities moved them to a sanitary residency, amid the neighbors' violence and media exposure (Emol, 2020). The increase in xenophobia has not only targeted Haitian and Venezuelan migrants; the country has also seen an increase in racism against the Asian communities living in Chile (Chan et al., 2020).

It can be argued that political and media discourse and some exclusionary actions have led to a hostile environment for immigrants. Another example is the so-called "humanitarian" return plan through which the government allowed Colombian migrants, who were in a vulnerable socio-economic situation in Chile, to fly from Santiago to Bogotá (MINREL, 2020), previous signature of a declaration by which they would have to agree to a 9 years prohibition of entry. This return plan is similar to the one initiated by the government in 2018 to repatriate Haitian migrants (Ministerio de Interior, 2018). The Supreme Court ruled the non-return clause contrary to the person's freedom of movement established in Article 19 No 7 of the Chilean Constitution (Corte Suprema de Chile, 2020).

By the end of April 2020, Piñera's administration put "urgency" to the discussion of the Migration and Foreigners Bill (Boletín No 8.970-06) in the Senate (Senate session 18/368), a resource through which the president can modify the legislative agenda by accelerating the discussion of the bill (Constitution of Chile, 1980, Art. 71). Both inside and outside Chile, civil society and academics issued warnings about several aspects of the bill ${ }^{12}$ (CELS, 2020), as well as the risks of discussing such an important law in the middle of the sanitary crisis and without substantial participation of civil society organizations (Diario UChile, 2020). The government justified the "urgency" of discussing the bill with the baseless estimate that around 500,000 migrants would arrive in the country after the pandemic (Schüller Gamboa, 2020). The bill was approved by the Senate in December 2020.

The emphasis on immigration by both the government and some media outlets in the middle of the sanitary crisis, evidences the strategic use and the politicization of immigration in Chile. The government's focus on the "urgent" discussion and approval of the Migration and Foreigners Bill in Congress, as well as the emphasis on the potential risk of transmission that immigrants could represent, can be understood as yet another attempt to shift media and public attention from the mishandling of the COVID-19 crisis to the "other"-the migrant-crisis (see Ramírez, 2020a). This framing of immigration reinforces political narratives that already existed before the pandemic. However, the challenges imposed to migrants' inclusion are not only discursive. The rhetoric runs alongside the explicit exclusion of migrants from some mitigation measures-due to irregular residency or expired documentation-(Vera Espinoza et al., Forthcoming), as well as exacerbated vulnerabilities produced by the sanitary and economic crisis (Bengochea et al., 2020; Zapata and Prieto Rosas, 2020).

${ }^{12}$ One example is the article 16 of the bill that restricts access to certain social benefits to immigrants with less than two years of legal residency in the country.

\section{PERU}

\section{Rising Immigration and Xenophobia}

Venezuelans are by far the largest and most politicized immigrant group in Peru, partly due to the rapid increase in numbers. In 2008, there were less than 3,000 foreigners with temporary or permanent residence, a number that rose to 54,000 in 2016. Since then, Peru has become home to more than 860,000 Venezuelan migrants according to United Nations data (R4V, 2020). By the end of 2019, Venezuelan immigrants made up $84.4 \%$ of all foreigners in Peru (Andina, 2019). Arequipa (with 3\% of the total Venezuelan population in Peru), Cusco (0.7\%), Lima (83.8\%), Tacna $(0.4 \%)$, and La Libertad $(3.9 \%)$ are the regions in which the majority of Venezuelans reside (Gestión, 2019). Other national origins of foreigners living in Peru include Colombia (3.6\%), Spain (1.3\%), the United States (1.0\%), Ecuador (1.0\%), Argentina (1.0\%), Chile (0.9\%), Brazil (0.9\%), and China (0.8\%) (Andina, 2019).

In addition to the steep increase in numbers, the sociodemographic characteristics of Venezuelans arriving in Peru have changed over time, with a tendency toward lower socioeconomic status and educational skills. More recent Venezuelan migrants arriving in Peru are poorer, less educated, and more vulnerable than their predecessors (Freier et al., 2019). Both factors - rising numbers and the change in social profile-led to a surge in xenophobic public opinion in Peru (Aron Said and Castillo Jara, 2020; Freier, 2020; Freier and Pérez, 2021). Perceptions of economic competition and migrants, as an additional burden for already precarious public services, led to an increasing percentage of the national population to oppose immigration (World Bank, 2019). Already by the end of 2018, 72\% of respondents in the capital Lima agreed with the statement that "the arrival of too many Venezuelans will harm the Peruvian economy," and 73\% agreed that "Venezuelan are taking away jobs from many Peruvians" (Instituto de Opinión Pública (IOP) and Instituto de Democracia y Derechos Humanos PUCP (IDEHPUCP), 2020). By the end of 2019, these percentages had risen to 77 and $76 \%$ respectively.

Between 2018 and 2019, a perceived link between immigration and crime added to the economic argument and worsened the public perception of Venezuelans, which generated pressure on the government to implement non-inclusive reception policies. While by the end of 2018, 55\% of respondents agreed with the statement that "many Venezuelans are responsible for criminal activities in Peru," this percentage increased to $81 \%$ by the end of 2019 (ibid.). This process was further fueled by stigmatizing reporting in the media and political discourses that criminalized Venezuelans, and specifically Venezuelan nationality (Freier and Pérez, 2021).

\section{Pre-COVID Narratives and Policies}

Peru reformed its outdated immigration law of 1991, which had a strong security focus, twice, through Legislative Decree 1,236 in 2015, and Legislative Decree 1,350 in 2017. Both reforms sought to simplify immigration legislation, protect the fundamental 
rights of national and foreign citizens, and strengthen national security. The 2017 law, which was the first to receive a regularizing decree, gave greater authority to the National Superintendence of Migration (Ministry of the Interior), simplified migratory statuses, facilitated the entry and stay of highly qualified foreigners, and strengthened the protection of vulnerable populations (Aron and Freier, 2020).

The Peruvian response to Venezuelan immigration has gone through two phases: openness under former president Pedro Pablo Kuczynski (July 2016-March 2018), and restrictiveness under incumbent president Martín Vizcarra (March 2018 - November 2020). Initially, Peru made significant advances in providing Venezuelans the necessary documentation to work. Although Peru did not apply the Southern Common Market (Mercosur) Residence Agreement or the Cartagena refugee definition (Acosta et al., 2019), it was the first country in the region to create a special residence permit for Venezuelan migrants: the Temporary Residence Permit (PTP), which was launched in early 2017, renewed four times ${ }^{13}$, and allowed Venezuelans to reside and work in Peru legally for one year.

However, the PTP program ended in December 2018 (applications could only be made by migrants who had entered by October of the same year). Roughly half a million Venezuelans received PTP status, and by mid 2020 , about 200,000 had been able to change to another temporary "special" residence status for a year (Freier and Brauckmeyer, 2020). In parallel, the Peruvian government introduced the requirement of a so-called "humanitarian" access visa in mid 2019, which had to be issued in Venezuela with a valid passport and certified clean criminal record-requirements that have long been prohibitive for most Venezuelans (Freier and Luzes, 2021). Entering, residing, and working regularly in Peru has since become much more difficult, if not impossible, for most Venezuelans, and the humanitarian visa presents an entry barrier to regular integration in practice.

This change in policy can be explained by an interplay between three factors: the change in number and social profiles of Venezuelan migrants, with a tendency toward lower social, economic, and educational statuses; and the rise in xenophobic attitudes among the Peruvian population, discussed above, as well as the internal political crisis, due to conflict between the executive and legislative branches of government (Aron Said and Castillo Jara, 2020). The standoff between executive and legislative, which led to the resignation of President Kucynski in March 2018 and culminated in the ousting of President Vizcarra and social unrest in November 2020, accentuated the latter's policy focus on domestic affairs and led to an approach to immigration that focused more on public opinion and less on foreign policy considerations.

${ }^{13}$ PTP 1: Supreme Decree No 002-2017-IN (January 3, 2017); PTP 2: Supreme Decree $N^{\circ} 023-2017$-IN (July 29, 2017); PTP 3: Supreme Decree $N^{\circ} 001-2018-I N$ (January 23, 2018) and PTP 4: Supreme Decree No007-2018IN (August 19, 2018).

\section{Narratives and Policies in the Context of COVID-19}

In the context of COVID-19, on March 16, Peru declared a state of emergency via Supreme Decree No 044-2020-PCM ${ }^{14}$, closing international borders and imposing compulsory social isolation. This measure was extended four times and lasted until June 30 (since then additional lockdowns were issued in regions with high infection rates). Borders remain closed and national and international transport suspended through Supreme Decrees $\mathrm{N}^{\circ}$ 044- 2020-PCM, 051-2020-PCM, 064-2020-PCM, 0802020-PCM and 094-2020-PCM. In addition, different curfews have been in place across the country. Exceptions to the abovementioned include the repatriation of Peruvians and return flights for foreigners organized in coordination with consulates and embassies. During the state of emergency, the armed forces actively participated in the vigilance of land and sea border crossings, both official and unofficial. For instance, in April, military vehicles were mobilized to the 22 clandestine crossings identified on the border with Ecuador. This was done in coordination with the Ecuadorian authorities and with "the exclusive aim of controlling the clandestine passages of illegal migrants" (Gestión, 2020).

In the case of foreigners who were already residing in Peru, some facilities were given to avoid sanctions due to irregularity during the state of emergency. Fines and administrative sanctions related to overstay were suspended (Resolución de Superintendencia $\mathrm{N}^{\circ} 100-2020$ and 104-2020). The use of provisional certificates was authorized for foreigners who had their Carné de Extranjería or PTP approved, but could not receive it due to compulsory social isolation (Resolución de Superintendencia No 121-2020). Additionally, and as we have seen in Chile, the virtual platform of the National Superintendence of Migration was strengthened. It is currently possible to carry out, and pay for, procedures for visa applications, change of migratory status, extension of residence permits, inscription for the issuance of the Carné de Extranjería, among other procedures, online.

Government measures to provide social and economic support for Peruvian families in vulnerable conditions, such as direct cash transfers (Bono Yo Me Quedo En Casa, Bono Independiente, Bono Rural, Bono Familiar Universal), did not include immigrants and refugees, since the national ID was required to access these. Legislative Decree 1,466 of April 21, 2020 authorized temporary affiliation to the public Integral Health Insurance (SIS) for all people who show symptoms or are diagnosed with COVID-19. However, this only applied for Peruvians and foreigners with Carné de Extranjería, which is not accessible for the majority of Venezuelan migrants due to the elevated procedural costs. Thus, the state did not consider the vulnerable situation in which many immigrants, and especially Venezuelan foreigners, found themselves, nor its public health implications. Rather, the government sought to transfer the

\footnotetext{
${ }^{14} \mathrm{https} / / /$ busquedas.elperuano.pe/normaslegales/decreto-supremo-que-declaraestado-de-emergencia-nacional-po-decreto-supremo-n-044-2020-pcm1864948-2/
} 
responsibility for assisting the most vulnerable migrants to international organizations, but without any coherent strategy or monitoring (Berganza et al., 2020).

Similar to the Chilean case, and in line with their institutional and ideological orientation, the Ministry of Foreign Affairs focused on issues related to the rights of Peruvians abroad and the strengthening of the work of Peruvian consulates, but did not assume its powers as the governing entity of the National Migration Policy, nor did it actively seek international funds for the inclusion of the migrant population in social emergency policies. On the other hand, the National Superintendence of Migration focused primarily on immigration control, supporting a questionable legislative project, as discussed below.

Some efforts were made to include migrant healthcare professionals in the fight against the pandemic. In April 2020, Emergency Decree No. 037-2020-PCM allowed the hiring of additional Peruvian and foreign health professionals to work in the fight against the pandemic in a special service called SERVICER. Hired professionals worked under a temporary contract and were granted life insurance paid by the state. However, according to the Peruvian Ombudsman's office ${ }^{15}$, bureaucratic barriers complicated the effective inclusion of these professionals, such as the non-recognition of their documents to open the bank accounts that they needed to receive their salaries. More recently, in August 2020, the Emergency Decree No. 090-2020 expanded the possibilities of hiring foreign healthcare workers by temporarily suspending the requirements of degree revalidation and inscription in the medical professional association. Both of these more inclusive policies, were limited to the state of emergency generated by the pandemic. It is still pending to see whether they will be continued in the post-COVID context.

More broadly, the COVID-19 pandemic led to a sharp decline in the link between Venezuelan immigration and crime made in the Peruvian media. At the same time, Peruvian civil society saw the pandemic as an opportunity to point out the need for migrant regularization. For example, the report of the Grupo Temático De Ciencias Sociales, commissioned by the Peruvian minister of health, included a chapter dedicated exclusively to the situation of Venezuelan immigrants in the country (Freier and Brauckmeyer, 2020). Despite these efforts, and the decline of political urgency of Venezuelan immigration, the Peruvian Congress presented various discriminatory laws during the quarantine period.

Five bills presented in the Peruvian Congress between 2019 and 2020 (PL 05625/2020 and PL 05349/2020 proposed by Acción Popular, PL 04830/2019 proposed by Fuerza Popular, PL 4844/ 2019 proposed by Contigo, and PL 4958/2020 proposed by Unión por el Perú) evidence the presence of xenophobic attitudes in some political parties. Guided by the perceived link between migration (particularly, irregular migration) and an increase in crime, PL 05625/2020 and PL 04844/2019 coincided in proposing special and fast mechanisms for the expulsion of migrants. For instance, PL 04844/2019 proposed the disproportionate sanction

\footnotetext{
${ }^{15}$ Interview with official from the Peruvian Ombudsman's office, July 6, 2020.
}

of expulsion for common crimes. Similarly, PL 05349/2020 proposed to invalidate the permits already granted to Venezuelan citizens (PTPs). Had this bill entered into force, it would have opened the door for the collective expulsion of Venezuelan migrants ${ }^{16}$.

In the context of the pandemic, PL 04958/2020 further proposed to repatriate vulnerable foreigners to their countries of origin, in an attempt to elude responsibility for the inclusion of migrants in the state's emergency response ${ }^{17}$. Finally, in relation to refugees, PL $04830 / 2019$ proposed to change, in a politicized manner, the composition of the two commissions in charge of deciding and reviewing asylum cases. The proposed new composition would have directly included the ministers of Foreign Affairs, Interior, and Justice, instead of the vice ministers or representatives, leading to the further politicization of the refugee determination process in Peru. Although it is unlikely that these bills will be passed, the fact that they were formally presented before the relevant state commissions shows that there was a serious attempt by the parliamentary groups to transform xenophobic misconceptions into enforceable law.

\section{DISCUSSION: COVID-19 AND IMMIGRANTS' INCREASED EXCLUSION}

At the time of editing this article, COVID-19 policy measures are ongoing. Chile's land borders closure has been renewed until January 2021 (Decree No 656, December 22, 2020). In both Chile and Peru, partial lock-downs continue. At the same time, Peru's Superintendence of Migration announced a regularization program in October 2020, establishing "special, exceptional and temporary" measures for the regularization of foreigners, of any nationality, through the issuance of a Temporary Permanence Permit Card (Carné de Permiso Temporal de Permanencia, CPP $)^{18}$. This new visa will be valid for one year and requires applicants to pay the overstay fines owed within a year after the approval of their application ${ }^{19}$.

The review of the immigration discourses and policies in Chile and Peru, both before and during the COVID-19 pandemic, offers relevant insights in relation to three key aspects: 1 . The lack of inclusion and sustainable integration policies for immigrants prior and during the pandemic; 2. The political immigration narratives that emerged in the context of the sanitary crisis, which offer insights on how actors in migration governance systems make sense of migration under the current scenario; and 3. The ways in which COVID-19 may be reframing migration governance in these two countries, and in the region, by reinforcing a securitized approach to migration that may

\footnotetext{
${ }^{16} \mathrm{PL}$ 05349/2020 was archived by the Congress' Commission on Foreign Affairs on 16th December 2020.

${ }^{17} \mathrm{PL}$ 04958/2020 was archived by Congress' Commission on Foreign Affairs on 16th December 2020.

${ }^{18}$ Supreme Decree 010-2020-IN of October 22.

${ }^{19}$ At the time of editing in January 2021, the CPP is not yet being issued as the Administrative Procedures (TUPA) have not yet been published.
} 
translate into the increased socio-economic and legal exclusion of migrant and refugee populations.

First, although many analysts have highlighted the initial relatively open and generous policy response by South American countries to Venezuelan displacement and increased intra-regional mobility (Acosta et al., 2019; Selee and Bolter, 2020), the majority of countries in the region, including Peru and Chile, passed ad hoc policies through presidential decrees, instead of applying existing and, overall, very progressive legislation (Acosta et al., 2019). In the context of Latin American presidentialism, this always bore the risk of leading to unstable policies that could change rapidly, depending on changing political inclinations and public opinion (Aron Said and Castillo Jara, 2020; Ramírez, 2020b). Indeed, even before the COVID-19 crisis, immigrants in both Chile and Peru were increasingly excluded in socio-economic terms. This can be explained by bureaucratic barriers to having their precarious legal status recognized both by state institutions and the private sector (e.g., banks and employers), and by the fact that immigrants increasingly found themselves in irregular status due to barriers to legal entry and stay.

Second, even before the onset of the COVID-19 pandemic, political narratives responded to the steep increase in the numbers of immigrants, and led to xenophobic backlashes, restrictive policy reactions, and related barriers to socio-economic inclusion of immigrants in both countries. Although there were some efforts to reframe the need for migrant regularization in the context of the pandemic, mainly spearheaded by civil society and migrant led-organizations, both in Chile and Peru, immigrants-particularly those without IDs or with irregular migration status - were excluded, in practice, from most of the social emergency policies during the pandemic, mirroring similar developments across the region (Vera Espinoza et al., Forthcoming). As mentioned above, in the case of Chile, immigrants have been directly associated with the spread of the virus.

Third, and perhaps most worrisomely, the pandemic has led to, or accelerated, legislative projects that envision the increased legal exclusion of immigrants in both countries, which will be detrimental for any efforts to counter their socio-economic exclusion and increasing vulnerability beyond the immediate context of the COVID-19 crisis. Here, the cases of Chile and Peru reflect a regional pattern of increased socio-economic and legal exclusion of immigrants and refugees, reflected by deeprouted vulnerabilities, hostile political narratives, and the emergence of restrictive policies (ibid.)

Overall, as in other world regions, in South America, the reframing of immigration will be essential. The multiple exclusions described in this paper have been challenged by

\section{REFERENCES}

Acosta, D., Blouin, C., and Feline Freier, L. (2019). La emigración venezolana: respuestas latinoamericanas. Madrid, Spain: Documento de Trabajo, no 3 (2a época) Fundación Carolina.

Acosta, D., Vera Espinoza, M., and Brumat, L. (2018). The new Chilean government and its shifting attitudes on migration governance. MPC migrant-led groups and civil society organizations. They demonstrate the need to move beyond the politics of immigration policies to the discussion of sustainable integration policies and broader practices of immigrant inclusion, understanding the need for facilitating-instead of restricting-regular migration to enable integration from a public health perspective, and to enable true socio-economic migrant inclusion, moving from a focus on national security toward human security (Ceriani Cernadas, 2020; Freier, 2020). The effects of COVID-19 on migrant and refugee populations make this task more timely, but also more difficult than ever.

\section{DATA AVAILABILITY STATEMENT}

The data presented in this article are not readily available because of confidentiality obligations toward the interviewees that participated in the study. Data discussed in this paper is also part of a larger study, which other outputs are still under development. Requests to access the datasets should be directed to Research Group CAMINAR, contacto@caminaramericas.org.

\section{ETHICS STATEMENT}

The study was reviewed and approved by the Queen Mary Ethics of Research Committee on May 19, 2020 (ref: QMERC2020/27). The participants provided their informed consent to participate in this study.

\section{AUTHOR CONTRIBUTIONS}

MVE wrote the section on Chile, and LF wrote the section on Peru. MVE led the introduction and LF the conclusion. Both authors contributed equally to the paper.

\section{ACKNOWLEDGMENTS}

Original data used in this paper is part of an ongoing multisited, regional and interdisciplinary project by the Research Group "Comparative Analysis on International Migration and Displacement in the Americas" (CAMINAR) www. caminaramericas.org. The authors thank Soledad Castillo Jara and Andrea Kvietok for their excellent research assistance, particularly with the section on Peru.

Blog. Available at: https://blogs.eui.eu/migrationpolicycentre/new-chileangovernment-shifting-attitudes-migration-governance/ (Accessed May 3).

Ambiado, C., Orrego, C., and Lages, R. (2020). Migración en tiempos de excepción: ¿con o sin papeles de identidad? Chile, CL: El Mostrador. Available at: https://www.elmostrador.cl/destacado/2020/04/09/migracion-en-tiemposde-excepcion-con-o-sin-papeles-de-identidad/ (Accessed April 9, 2020).

Andina (2019). ¿Cuántos extranjeros residen en el Perú y dónde trabajan? Portland, OR: Andina. Available at: https://andina.pe/agencia/noticia-\%C2\% 
BFcuantos-extranjeros-residen-el-peru-y-donde-trabajan-778866.aspx. (Accessed December 22, 2019).

Aron, V., and Freier, L. F. (2020). "La legislación migratoria en Perú: entre la promoción de los derechos humanos y la seguridad nacional," in Politicas y reformas migratorias en América Latina. Editor N. Caicedo Camacho (Lima, Peru: Fondo Editorial de la Universidad del Pacífico), 207-230.

Aron Said, V., and Castillo Jara, S. C. (2020). Reacting to change within change: adaptive leadership and the Peruvian response to Venezuelan immigration. Int. Migration doi:10.1111/imig.12761

BBC Mundo (2020). Coronavirus: identifican primer caso de covid-19 en Chile. London, United Kingdom: BBC News Mundo. Available at: https://www.bbc. com/mundo/noticias-america-latina-51729957. (Accessed March 3, 2020).

Bengochea, J., Cabezas, G., Gandini, L., Herrera, G., Luzes, M., Montiel, C., et al. (2020). "COVID-19 y población migrante y refugiada. Análisis de las respuestas político-institucionales en ciudades receptoras de seis países de América Latina," in Inmigrando: comprender Ciudades en Transición. Editors F. Vera, V. Adler, and F. Toro (Buenos Aires, AR: BID), Vol. 3, 749-782.

Berganza, I., Blouin, C., and Feline Freier, L. (2020). El elemento situacional de violación masiva de derechos humanos de la definición ampliada de Cartagena: hacia una aplicación en el caso venezolano. Revista Chilena de Derecho 47 (2), 385-410. doi:10.4067/S0718-34372020000200385

Berganza, I., and Freier, L. F. (2021). "Política Migratoria y de Refugio: hacia una Política de Integración para un País de Acogida," in Proyecto Bicentenario: contribuciones al Perú en Camino a su Desarrollo. (Lima, Peru: Universidad del Pacífico).

Bonhomme, M. (2021). Racismo en barrios multiculturales en Chile: pre-cariedad habitacional y convivencia en contexto migratorio. Bitácora Urbano Territorial 31 (I), 167-181. doi:10.15446/bitacora.v31n1.88180

Brumat, L. (2020). "Four generations of regional policies for the (free) movement of persons in South America (1977-2016)," in In regional integration and migration in the global South. Editors K. Marchand, G. Rayp, and R. Ilse (New York, NY: Springer-United Nations University).

Brumat, L., and Vera Espinoza, M. (Forthcoming). Migration policy change in Argentina, Brazil and Chile: the Re-emergence of the 'securitist' actors.

Cabieses, B., Libuy, M., and Dabanch, J. (2019). Hacia una compresión integral de la relación entre migración internacional y enfermedades infecciosas. De la creencia a la evidencia para la acción sanitaria en Chile. Santiago, CL: Colegio Medico de Chile.

Carreño, C. (2020). Covid 19: cuando las políticas públicas discriminan por ser inmigrante. Santiago, CL: Diario Constitucional.cl. Available at: https://www. diarioconstitucional.cl/articulos/covid-19-cuando-las-politicas-publicas-discriminanpor-ser-inmigrante/ (Accessed September 20, 2020).

CELS (2020). Preocupación Internacional por el Proyecto de Ley de Migración y Extranjería, en Chile. Carta Abierta. Available at: https://www.cels.org.ar/web/ 2020/08/chile-preocupacion-internacional-por-el-proyecto-de-ley-de-migraciones/. (Accessed August 18, 2020).

CEPAL (2019). Observatorio Demográfico América Latina y el Caribe 2018. (LC/ PUB.2018/25-P), Santiago.

Ceriani Cernadas, P. (2020). Migratory regularization as an essential condition for the comprehensive protection of the rights of children in the context of human mobility. Technical Note, UNICEF Latin America and Caribbean Regional Office. Available at: https://www.unicef.org/lac/en/reports/migratory-regularizationessential-condition-comprehensive-for-children-protection. (Accessed May, 2020).

Chan, C., and Montt Strabucchi, M. (2020). Many-faced orientalism: racism and xenophobia in a time of the novel coronavirus in Chile. Asian Ethn. 22, 374. doi:10.1080/14631369.2020.1795618

Cook, M. L. (2013). "Is incorporation of unauthorized immigrants possible? Inclusion and contingency for nonstatus migrants and legal immigrants," in Outsiders No more?: models of immigrant political integration. Editors J. Hochschild, J. Chattopadhyay, C. Gay, and M. J. Correa (Oxford Scholarship Online). doi:10.1093/acprof:oso/9780199311316.003.0003

Corte Suprema de Chile (2020). The Supreme Court ruling in Chile is $\mathrm{N}^{\circ}$ Amparo1402-2020.

Doña-Reveco, C., and Levinson, A. (2012). Chile: a growing destination country in search of a coherent approach to migration. Washington, DC: Migration Information Source.
Emol (2020). SJM acusa discriminación a extranjeros de cité donde hubo brote de covid-19: "El problema no son ellos, sino el racismo". Emol. Available at: https:// www.emol.com/noticias/Nacional/2020/04/22/983935/SMJ-discriminacion-citeQuilicura-coronavirus.html. (Accessed April 22, 2020).

Finn, V., and Umpierrez de Reguero, S. (2020). Inclusive Language for exclusive policies: restrictive migration governance in Chile, 2018. Latin Am. Policy 11 (1), 42-61. doi:10.1111/lamp.12176

Freier, L. F., Berganza, I., and Blouin, C. (2020). The Cartagena refugee definition and Venezuelan displacement in Latin America. International Migration.

Freier, L. F., and Brauckmeyer, G. (2020). "Migrantes venezolanos y COVID-19: impacto de la cuarentena y propuestas para la apertura," in Por una nueva convivencia. La sociedad peruana en tiempos de COVID-19: escenarios, propuestas de política y acción pública. Editors M. Burga, F. Portocarrero, and A. Panfichi. (Lima: Fondo Editorial PUCP)

Freier, L. F. (2020). Covid-19 and the transformation of migration and mobility globally - COVID-19 and rethinking the need for legal pathways to mobility: taking human security seriously. Available at: https://publications.iom. int/books/covid-19-and-transformation-migration-and-mobility-globallycovid-19-and-rethinking-need-legal (Accessed September 5, 2020).

Freier, L. F., Luzes, M., and Bolívar, L. (2019). Propuesta de Política Pública ${ }^{\circ} 2$ : los impactos adversos de las visas humanitarias. Paris, France: CIUP. Available at: https://ciup.up.edu.pe/media/1583/ciup-ppp-no2.pdf (Accessed June 8, 2020).

Freier, L. F., and Luzes, M. (2021). "How humanitarian are humanitarian visas? An analysis of theory and practice in South America," in Latin America and Refugee Protection: regimes, logics and challenges. Editors L. Jubilut, G. Mezzanotti, and M. Vera Espinoza (New York, NY: Berghahn).

Freier, L. F., and Pérez, L. (2021). Criminalisation of south-south migration: the experience of Venezuelan forced migrants in Peru. Eur. J. Criminal Policy Res. doi:10.1007/s10610-020-09475-y

A. Geddes, M. Vera Espinoza, L. Hadj-Abdou, and L. Brumat (Editors) (2019). The Dynamics of regional migration governance (Cheltenham, England: Edward Elgar Publishing).

Gestión (2020). Coronavirus: refuerzan vigilancia en 22 puntos clandestinos identificados en la frontera con Ecuador. Available at: https://gestion.pe/ peru/coronavirus-en-peru-refuerzan-vigilancia-en-22-puntos-clandestinosidentificados-en-la-frontera-con-ecuador-nnpp-noticia/. (Accessed April 4, 2020).

Gestión (2019). ¿Dónde se ubican los ciudadanos venezolanos en el Perú por domicilio y trabajo? Available at: https:/gestion.pe/economia/empresas/ ubican-ciudadanos-venezolanos-peru-domicilio-270124-noticia/. (Accessed June 13, 2019).

Gidley, B. (2014). "Integration," in Migration: the COMPAS anthology. Editors B. Anderson and M. Keith (Oxford, England: COMPAS).

Gobierno de Chile (2020). Congreso aprobó la Ley de Migración y Extranjería y quedó en condiciones de ser promulgada. Gob.cl. Available at: https://www.gob. cl/noticias/congreso-aprobo-la-ley-de-migracion-y-extranjeria-y-quedo-encondiciones-de-ser-promulgada/. (Accessed December 3, 2020).

González, R., Muñoz, E., and Mackenna, B. (2019). "Como quieren en Chile al amigo cuando es forastero: actitudes de los chilenos hacia la inmigración" in Isabel Aninat and Rodrigo Vergara (des), Inmigración en Chile. Una mirada multidimensional. CEP: Santiago de ChileFCE, 321-346.

INE (2018). Resultados Censo 2017. Chile: Instituto Nacional de Estadísticas. Santiago, Abril de 2018.

IMF (2020). Policy responses to COVID-19. International monetary fund. Available at: https://www.imf.org/en/Topics/imf-and-covid19/Policy-Responses-toCOVID-19\#C (Accessed September 2, 2020).

INE-DEM (2020). Estimación de Personas Extranjeras Residentes en Chile al 31 de Diciembre 2019. Santiago, Chile: Informe Técnico, Instituto Nacional de Estadísticas y Departamento de Extranjería y Migración.

Instituto de Opinión Pública (IOP) and Instituto de Democracia y Derechos Humanos PUCP (IDEHPUCP) (2020). Cambios en las actitudes hacia los inmigrantes venezolanos en Lima-Callao 2018-2019. Available at: http:// repositorio.pucp.edu.pe/index/bitstream/handle/123456789/169459/IOP 1119_01_R2.pdf?sequence=1\&isAllowed $=y$ (Accessed June 6, 2020).

La Tercera (2019). Aclaración sobre artículo publicado por La Tercera: un error del que nos hacemos cargo. La Tercera. Available at: https://www.latercera.com/ 
nacional/noticia/aclaracion-articulo-publicado-la-tercera-error-del-nos-hacemoscargo/881975/. (Accessed October 28, 2019).

L. L. Jubilut, M. Vera Espinoza, and G. Mezzanotti (Editors) (2021). Latin America and Refugee Protection: regimes, logics and challenges (New York, NY: Berghahn Books).

Luzes, M., Freier, L. F., and Castillo Jara, S. (2020). Propuesta de Política Pública $\mathrm{N}^{\circ}$ 10: La necesaria regulación migratoria durante la crisis sanitaria. CIUP. Available at: https://ciup.up.edu.pe/ppp/la-necesaria-regulacion-migratoriadurante-crisis-sanitaria/ (Accessed October 10, 2020).

Mazza, J. (2020). Venezuelan migrants under COVID-19: managing South America's pandemic amid a migration crisis. Latin American Program Working Paper. Washington: Wilson Center.

Ministerio de Interior (2018). Comienza inscripción de migrantes en el Plan de Retorno Humanitario al país de origen. Noticias Interior.gob.cl. Available at: https://www.interior.gob.cl/noticias/2018/10/17/comienza-inscripcion-de-migrantesen-el-plan-de-retorno-humanitario-al-pais-de-origen/. (Accessed October 17, 2018).

Ministerio de Justicia y Derechos Humanos (MJDDHH) (2020). Diario Oficial de la República de ChileMinisterio del Interior y Seguridad Pública. Normas Generales CVE 1747658. Available at: https://www.diariooficial.interior.gob.cl/ publicaciones/2020/04/01/42621/01/1747658.pdf. (Accessed November 15, 2020).

MINREL (2020). Cancillería dispondrá un vuelo humanitario para repatriar a colombianos varados en Chile. Noticias Ministerio de Relaciones Exteriores. Available at: https://minrel.gob.cl/minrel/noticias-anteriores/cancilleria-dispondraun-vuelo-humanitario-para-repatriar-a-colombianos (Accessed June 3, 2020).

Marrow, H. B. (2009). Immigrant bureaucratic incorporation: the dual role of professional missions and government policies. Am. Sociological Rev. 74 (5), 756-776. doi:10.1177/000312240907400504

Navarrete, M. J., and Vedoya, S. (2019). Ordenar la casa": análisis del primer año de la política migratoria del gobierno. La Tercera. Available at: www.latercera.com/ nacional/noticia/ordenar-la-casa-analisis-del-primer-ano-la-politica-migratoriadel-gobierno/604018/. (Accessed April 6, 2019).

Prensa Presidencia (2020). Presidente inicia visita a las regiones de Biobío y Ñuble para supervisar operaciones de apoyo de las Fuerzas Armadas por coronavirus. Prensa Presidencia. Available at: https://prensa.presidencia.cl/discurso.aspx? id $=149807$. (Accessed April 10, 2020).

R4V (2020). Coordination platform for refugees and migrants from Venezuela. Available at: https://r4v.info/es/situations/platform (Accessed November 9, 2020).

Ramírez, C. (2020a). Discursos anti-inmigración y su posición privilegiada en los medios: una amenaza a la convivencia. CIPER Chile. Available at: https:// ciperchile.cl/2020/05/20/discursos-anti-inmigracion-y-su-posicion-privilegiadaen-los-medios-una-amenaza-a-la-convivencia/. (Accessed May 5, 2020).

Ramírez, J. (2020b). De la ciudadanía suramericana al humanitarismo: el giro en la política y diplomacia migratoria ecuatoriana. Ref 21. doi:10.21670/ref.2019061

Red de Migrantes por el Apruebo (2020). La participación migrante debe continuar en el proceso constituyente. Santiago, CL: Declaration.

Selee, A., and Bolter, J. (2020). An uneven welcome: Latin American and caribbean responses to Venezuelan and Nicaraguan migration. Washington, DC: Migration Policy Institute. Available at: https://www.migrationpolicy.org/research/latamcaribbean-responses-venezuelan-nicaraguan-migration (Accessed July 25, 2020).
Stefoni, C.., and y. Brito, S. (2019). "Chile: un destino más en el mapa migratorio intrarregional," in Migración en Chile. Evidencias y mitos de una nueva realidad. Editors. N. R. Pedemonte and V. José Tomás. Santiago, CL: LOM ediciones, $23-48$.

Schüller Gamboa, P. (2020). Gobierno llama al Senado a rechazar indicaciones de la oposición a ley de migración. La Nación. Available at: http://www.lanacion.cl/ gobierno-llama-al-senado-a-rechazar-indicaciones-de-la-oposicion-a-ley-demigracion/. (Accessed August 11, 2020).

Thayer, L. E. (2019). "Causas y consecuencias de La irregularidad migratoria," in Migración in Chile. Evidencias y Mitos de una nueva realidad. Editors N. Rojas Pedemonte and J. Tomás Vicuña (Santiago, CL: LOM Ediciones), 297-334.

M. E. Tijoux and y. C. Ambiado (Editors) (2019). Racismo y Migración Contemporánea en Chile. Informe alternativo para el Comité para la Eliminación de la Discriminación Racial (CERD). Cátedra de Racismos y Migraciones Contemporáneas (Universidad de Chile y Movimiento Acción Migrante. ). Available at: https://www.uchile.cl/noticias/159487/catedra-deracismos-y-migraciones-entrega-informe-a-la-onu. (Accessed October 31, 2019).

UNAB-DEM (2020). Sondeo de percepción sobre migración en Chile. Síntesis de resultados. Centro de Políticas Públicas Universidad Andres Bello. Available at https://www.extranjeria.gob.cl/media/2020/06/20200615-Resultados-EncuestaMigracio\%CC\%81n-en-Chile-UNAB-DEM.pdf (Accessed August 4, 2020).

Vera Espinoza, M., Prieto, V., Zapata, G., Gandini, L., Herrera, G., Reguera, A., et al. (Forthcoming). Migrants and refugees in Latin America during COVID19: an inclusion/exclusion spectrum of social protection.

Vera Espinoza, M., Zapata, G. P., and Gandini, L. (2020). Mobility in immobility: Latin American migrants trapped amid COVID-19. United Kingdom: OpenDemocracy. Available at: https://www.opendemocracy.net/en/ democraciaabierta/mobility-immobility-latin-american-migrants-trapped-amidcovid-19/. (Accessed May 26).

World Bank (2019). Una oportunidad para todos. Los migrantes y refugiados venezolanos y el desarrollo del Perú. Washington, DC: World Bank.

Zapata, G. P., and Prieto Rosas, V. (2020). Structural and contingent inequalities: the impact of COVID -19 on migrant and refugee populations in South America. Bull. Lat. Am. Res. 39 (S1), 16-22. doi:10.1111/blar.13181

Conflict of Interest: The authors declare that the research was conducted in the absence of any commercial or financial relationships that could be construed as a potential conflict of interest.

The reviewer MC declared a shared committee with one of the authors MVE at time of review.

Copyright (c) 2021 Freier and Vera Espinoza. This is an open-access article distributed under the terms of the Creative Commons Attribution License (CC $B Y)$. The use, distribution or reproduction in other forums is permitted, provided the original author(s) and the copyright owner(s) are credited and that the original publication in this journal is cited, in accordance with accepted academic practice. No use, distribution or reproduction is permitted which does not comply with these terms. 